\title{
Viability of Simira gardneriana M.R. Barbosa \& Peixoto seeds by the tetrazolium test ${ }^{1}$
}

\author{
Fabrícia Nascimento de Oliveira ${ }^{2}$, Salvador Barros Torres ${ }^{3 *}$, \\ Narjara Walessa Nogueira ${ }^{3}$, Rômulo Magno Oliveira de Freitas ${ }^{3}$
}

\begin{abstract}
Ecoregion Caatinga presents a great diversity of species with potential for exploitation. Among them 'pereirovermelho' (Simira gardneriana M.R. Barbosa \& Peixoto) stands out for its importance in timber and forestry activities. Its seeds germinate slowly. Therefore, the use of tetrazolium test to estimate viability becomes essential when quick answers on seeds quality are wanted. This study has aimed to establish the best concentration of tetrazolium solution and the coloration period for assessing the viability of Simira gardneriana seeds. Initially, seeds were subjected to pre-wetting between paper sheets for 144 hours at $30{ }^{\circ} \mathrm{C}$. Subsequently, the endosperm portion containing the embryo was immersed at four concentrations of tetrazolium solution $(0.075,0.1,0.5$ and $1.0 \%)$ and three coloration periods (2, 4 and 6 hours) in the dark under the temperature of $30^{\circ} \mathrm{C}$ and another one at $35^{\circ} \mathrm{C}$. The percentage of viable seeds was compared with the results obtained in the germination test conducted on paper substrate at $30^{\circ} \mathrm{C}$ in four replicates of 25 seeds. Tetrazolium test was efficient to estimate the viability of $S$. gardneriana seed and the concentration of $0.075 \%$ for six hours at $35^{\circ} \mathrm{C}$ was the best condition.
\end{abstract}

Index terms: Rubiaceae, forest seeds, caatinga, germination, conservation.

\section{Viabilidade de sementes Simira gardneriana M.R. Barbosa \& Peixoto pelo teste de tetrazólio}

\begin{abstract}
RESUMO - A Caatinga apresenta grande diversidade de espécies com potencial de exploração, dentre estas o pereirovermelho (Simira gardneriana M.R. Barbosa \& Peixoto) destaca-se pela importância nas atividades madeireira e florestal. Suas sementes germinam lentamente, com isso o uso do teste de tetrazólio para estimar a viabilidade passa a ser essencial quando se deseja respostas rápidas sobre a qualidade das sementes. Assim, objetivou-se com esse trabalho estabelecer a melhor concentração da solução de tetrazólio e o período de coloração para a avaliação da viabilidade de sementes de S. gardneriana. Inicialmente, as sementes foram submetidas ao pré-umedecimento entre papel por 144 horas a $30{ }^{\circ} \mathrm{C}$. Posteriormente, a porção do endosperma contendo o embrião foi imersa em quatro concentrações da solução de tetrazólio $(0,075 ; 0,1 ; 0,5$ e $1,0 \%)$ e três períodos de coloração (2, 4 e 6 horas), no escuro, sob a temperatura de $30^{\circ} \mathrm{C}$ e outra a $35^{\circ} \mathrm{C}$. A porcentagem de sementes viáveis foi comparada com os resultados obtidos no teste de germinação, conduzido em substrato papel, a $30^{\circ} \mathrm{C}$, em quatro repetições de 25 sementes. O teste de tetrazólio foi eficiente para estimar a viabilidade de sementes de S. gardneriana, sendo a concentração de $0,075 \%$ por seis horas, a $35^{\circ} \mathrm{C}$ a melhor condição.
\end{abstract}

Termos para indexação: Rubiaceae, sementes florestais, caatinga, germinação, conservação.

\section{Introduction}

S. gardneriana M.R. Barbosa \& Peixoto, known as pereiro-vermelho, is an endemic species of the Caatinga, which stands out for its timber, dyeing, craftsmanship and landscape values (Barbosa and Peixoto, 2000). However, the lack of studies on this species is one of the barriers which limit its use, especially with regard to handling, quality and

${ }^{1}$ Submitted on 8/21/2015. Accepted for publication on 11/22/2015. ${ }^{2}$ Departamento de Ciências Ambientais e Tecnológicas, Universidade Federal Rural do Semi-Árido, 59515-000 - Mossoró, RN, Brasil. viability of the seeds.

Although $S$. gardneriana seeds do not show dormancy, germination occurs slowly, making it difficult to obtain results when quick information is wanted. In this context, tetrazolium test has been shown to be a promising alternative in determining seeds viability and vigor of various forest species for the quality and speed in obtaining results. This test reflects the activity of dehydrogenase enzymes involved

${ }^{3}$ Departamento de Ciências Vegetais, Universidade Federal Rural do SemiÁrido, Caixa Postal 137, 59625-900 - Mossoró, RN, Brasil.

*Corresponding author < sbtorres@ufersa.edu.br> 
in the breathing process, whose seeds living and dead tissues are identified by the presence or absence of the color red, respectively (AOSA, 2009).

Recent research in forest species seeds has been developed, aiming to reduce the time required to obtain viability results, from the verification of the most appropriate methodology of tetrazolium test for each species, according to work carried out by Fava and Albuquerque (2013) on Palicourea rigida Kunth; Abbade and Takaki (2014) on Tabebuia roseoalba (Ridl.) Sandwith; Cripa et al. (2014), Kaiser et al. (2014) and Lamarca and Barbedo (2014) on species of the genus Eugenia; and Nogueira et al. (2014) on Pacara Earpod Tree (Enterolobium contortisiliquum (Vell.) Morong).

Several factors can interfere with satisfactory results in the tetrazolium test, especially those related to the criteria for interpreting the findings and methods of execution (GasparOliveira et al., 2009). Among the implementation procedures before performing this test is preconditioning, which aims the solution penetration in the tissues of interest to be evaluated (Brasil, 2009). In this sense, for seeds of Ceiba speciosa (A. St. - Hil.) Ravenna), Lazarotto et al. (2011) recommend immersion in water at room temperature for eight hours; Abbade and Takaki (2014) recommend for seeds of $T$. roseoalba immersion in water for $12 \mathrm{~h}$ at $25^{\circ} \mathrm{C}$; and for seeds of Pacara Earpod Tree (E. contortisiliquum (Vell.) Morong), Nogueira et al. (2014) recommend chiseling followed by soaking in water for $24 \mathrm{~h}$ and removal of the integument.

As regards the coloration period, the tetrazolium salt concentration and the incubation temperature directly interfere in the coloration intensity and uniformity of the seeds tissues, depending on the characteristics of each species (AOSA, 2009). The definition of these factors is important as they influence the assessment and interpretation of test results. Considering the variables involved in the tetrazolium test, there is a concern among researchers in adapting the methodology for assessment of native forest seeds. For seeds of Tabebuia serratifolia Vahl Nich., immersion in $0.5 \%$ tetrazolium solution for 12 hours at $30{ }^{\circ} \mathrm{C}$ is used and in seeds of Peltophorum dubium (Sprengel) Taubert, the solution concentration used is $0.1 \%$ and temperature of $25^{\circ} \mathrm{C}$ for 150 minutes of coloration (Oliveira et al., 2005a; 2005b). For seeds of Piptadenia moniliformis Benth., Azerêdo et al. (2011) recommend coloration in tetrazolium solution at $0.075 \%$ for four hours at $35^{\circ} \mathrm{C}$. For seeds of Eugenia uniflora L., Kaiser et al. (2014) recommend the tetrazolium test at $0.5 \%$ for 2 hours at $30{ }^{\circ} \mathrm{C}$. And for seeds of Pacara Earpod Tree, Nogueira et al. (2014) recommend seeds immersion in tetrazolium solution at $0.075 \%$ at $35{ }^{\circ} \mathrm{C}$ for three hours.

Based on the above, this work aimed to establish the best tetrazolium solution concentration and coloration period to assess the viability of $S$. gardneriana seeds.

\section{Material and Methods}

The research was developed at the Seed Testing Laboratory of the Plant Sciences Department at UFERSA, in the Brazilian city of Mossoró, RN, with seeds of S. gardneriana granted by the Centro de Referência para Recuperação de Áreas Degradadas da Caatinga (Reference Center for Recovery of Degraded Areas of the Caatinga) at Federal University of São Francisco Valley (UNIVASF, Universidade Federal do Vale do São Francisco), in the Brazilian city of Petrolina, PE. The seeds were collected from various matrix trees located in the Brazilian municipality of Afrânio, PE ( $8^{\circ} 30^{\prime} 42^{\prime \prime} \mathrm{S} ; 41^{\circ} 00^{\prime} 36^{\prime \prime}$ $\mathrm{W}$ and $540 \mathrm{~m}$ altitude) in December 2009.

Before conducting the experiments, the seeds were packed in paper bags and stored in cold storage $\left(10-12{ }^{\circ} \mathrm{C}\right.$ and $50-52 \% \mathrm{RH}$ of the environment) for five years.

Preliminarily, seeds soaking curve was determined using four replicates of 25 seeds distributed in three sheets of paper towel moistened with water equivalent to 2.5 times the dry weight of the substrate and maintained in a B.O.D. (Biochemical Oxygen Demand) growth chamber at $30{ }^{\circ} \mathrm{C}$. The initial fresh weight of the various seeds subsamples was recorded before soaking and after the seeds were removed, dried in absorbent paper and weighed $(0.001 \mathrm{~g})$ in three-hour intervals in the first $15 \mathrm{~h}$ and in six-hour intervals between 15 and $33 \mathrm{~h}$. Then, weighings were taken at 12-hour intervals between 33 and $81 \mathrm{~h}$, and finally at 24-hour intervals until the moment when stabilization of the seed weight was noticed due to the maximum water absorption. Thus, the immersion was defined as the weight increase relative to the initial weight.

The determination of the initial moisture content of the seeds was performed by the oven method at $105^{\circ} \mathrm{C} \pm 3{ }^{\circ} \mathrm{C}$ for 24 hours (Brasil, 2009) using four replications of three grams of seeds and the results expressed as a percentage (wet basis).

For the tetrazolium test, the $S$. gardneriana seeds were premoistened in paper towel and placed in a germination chamber at $30^{\circ} \mathrm{C}$ for 144 hours, according to results from the soaking curve. Next, with a scalpel, seeds were longitudinally and medially cut, with the endosperm portion containing the embryo placed in 50 $\mathrm{mL}$ plastic cups and immersed in a solution of 2,3,5 triphenyl tetrazolium chloride at four concentrations of $0.075 ; 0.1 ; 0.5$ and $1.0 \%$ for three coloration periods ( 2,4 and 6 hours) in a chamber regulated at a temperature of $30^{\circ} \mathrm{C}$ and the other one at $35^{\circ} \mathrm{C}$ in the dark. Four replications of 25 seeds were used for each concentration combination of the tetrazolium solution and coloration period for experiments involving the incubation temperatures. 
After the coloration period, the solution was drained, the material washed in running water, and the embryos were extracted from the remaining part of the endosperm and kept in water in a refrigerated environment until evaluation. Subsequently, the embryos were individually observed with a magnifying stereoscopic and evaluated for uniformity, color intensity, presence of milky white areas, tissues appearance and location of these colorations in relation to the essential areas of the embryo (hypocotyl-radicle axis and vascular area), being classified into viable and unviable, in accordance with standards specified by AOSA (Association of Official Seed Analysts) (2009) and Brasil (2009), for various agricultural and forest species: 1) viable: embryos with full coloration in light pink or bright red; radicle end without a milky white/yellowish coloration; and 2) unviable: embryos with full coloration in crimson red/intense red or milky white/yellowish; radicle end without coloration or an intense red coloration. Results were expressed as percentage of viable seeds.

To compare the results obtained in the tetrazolium test, germination test was conducted in a B.O.D. (Biochemical Oxygen Demand)-type growth chamber at $30{ }^{\circ} \mathrm{C}$ under constant white light, with four replications of 25 seeds. The seeds were distributed on paper towel rolls moistened in water equivalent to 2.5 times the mass of the dry substrate and placed inside transparent plastic bags to keep moisture. The criteria used for seed germination was the development of normal seedlings (Brasil, 2009), and assessment was carried out on the thirtieth day after sowing.

The experimental design used was a completely randomized one in a $4 \times 3+1$ factorial arrangement (4 concentrations of tetrazolium solution $\mathrm{x} 3$ periods of coloration +1 control - germination test) at a temperature of $30{ }^{\circ} \mathrm{C}$ and the other one at $35^{\circ} \mathrm{C}$ in four replications of 25 seeds for each treatment. The data were submitted to normality and homogeneity test of variances to assess the need for transformation. Sequentially, analysis of variance (ANOVA) was performed by the F-test at $1 \%$ and $5 \%$ significance and means of viable seeds obtained by the tetrazolium test were compared by Tukey's test ( $\mathrm{p} \leq 0.05)$. The comparison between the means of viable seeds for each of the combinations in the tetrazolium test with the results of the germination test (control) were carried out by the Dunnett's test ( $\mathrm{p} \leq 0.05$ ). Statistical analyses were performed using the software ASSISTAT version 7.6 beta (Silva and Azevedo, 2002).

\section{Results and Discussion}

S. gardneriana seeds present stabilization in water absorption from 33 hours after the start of soaking (Figure 1), demonstrating that this process is slow, completing Phase I in more than $24 \mathrm{~h}$ of moisturizing.

The initial moisture content of the seeds was $12.3 \%$. However, it was found that after pre-wetting, Phase II of the three-phase model of hydration reached moisture between 69.9 and $77.3 \%$ for 33 and 153 hours of hydration, respectively (Figure 1). In this hydration period, the seeds completed Phase II with radicle emission, thereby being observed that this hydration period is sufficient to reactivate the embryo metabolism.

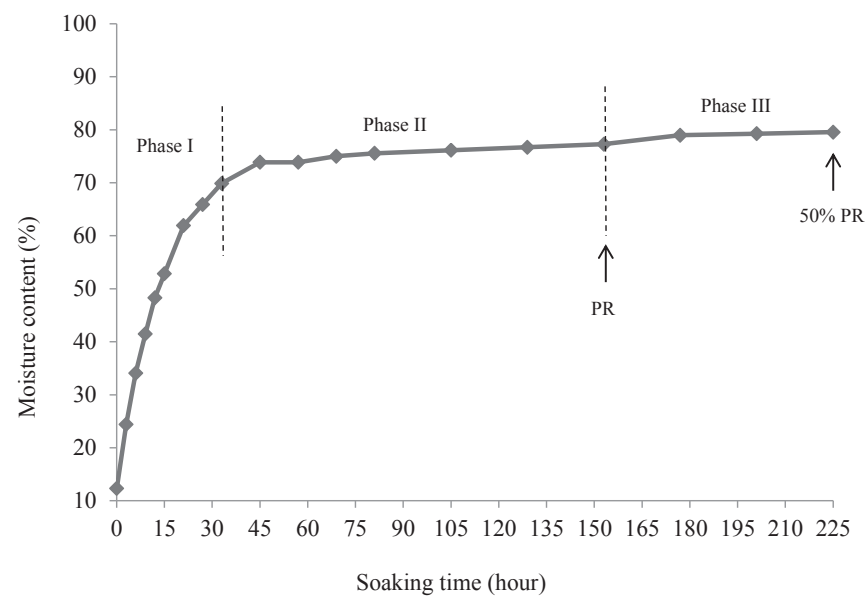

Figure 1. Soaking curve of seeds of Simira gardneriana M.R. Barbosa \& Peixoto at a temperature of $30{ }^{\circ} \mathrm{C}$. PR = Protrusion of the radicle; $50 \% \mathrm{PR}=$ Protrusion of the radicle in $50 \%$ of seeds.

It was also observed that Phase I showed rapid water uptake during the first 33 hours and Phase III began at 153 hours after initiation of hydration. Thus, it was possible to perform the soaking curve of the $S$. gardneriana seeds by establishing the premoistening period (144 hours), i.e., the time required for the seeds to reach Phase II intermediate, avoiding that they reached Phase III (153 hours). Pre-wetting corresponds to the seeds preparation phase to facilitate penetration of the tetrazolium solution and development of a uniform coloration (Brasil, 2009). Besides, according to Marcos-Filho et al. (1987) and AOSA (2009), pre-hydration favors not only tissues softening, integument removal and longitudinal section of the embryos, but also provides a clearly evident coloration, improved test quality and makes assessment easier.

According to Zonta et al. (2009), what is recommended for the Coffea arabica L. seeds is soaking for 24 hours at $30{ }^{\circ} \mathrm{C}$. Although the species of this study is from the same botanical family, the time recommended is insufficient to soften the $S$. gardneriana seeds, which complicates the extraction of embryos. Thus, in this study the pre-wetting 
period recommended may be 144 hours of soaking for the occurrence of sufficient activation of the enzyme system, which improves and speeds up the coloration process.

After determining the pre-wetting period (144 hours), embryos were exposed to concentrations of tetrazolium solution and coloration periods at each temperature $\left(30\right.$ and $\left.35^{\circ} \mathrm{C}\right)$. There was no difference for the concentration factor of the tetrazolium solution at $30{ }^{\circ} \mathrm{C}$, but at $35{ }^{\circ} \mathrm{C}$ this factor showed significance of
$1 \%$ in the F-test. There was a significant effect of $1 \%$ probability of the coloration period factor and the interaction between the solution concentration and coloration period factors for experiments conducted at temperatures of 30 and $35^{\circ} \mathrm{C}$. In addition, there was a significant difference between the estimates of seed viability obtained by the tetrazolium test and the results of the germination test, as can be seen by the significance of the control (germination percentage) versus factorial contrast (Table 1).

Table 1. Summary of the analysis of variance seen in the tetrazolium test of seeds Simira gardneriana M.R. Barbosa \& Peixoto compared to the results of the germination test (control).

\begin{tabular}{lrc}
\hline \multicolumn{1}{c}{ Sources of variation } & \multicolumn{2}{c}{ Mean square } \\
\cline { 2 - 3 } & Temperature $\left(30^{\circ} \mathrm{C}\right)$ & Temperature $\left(35^{\circ} \mathrm{C}\right)$ \\
\hline Treatments & $1359.692^{* *}$ & $4251.026^{* *}$ \\
Control vs Factorial & $11996.308^{* *}$ & $5123.308^{* *}$ \\
Concentration of tetrazolium solution (C) & $127.111^{\text {ns }}$ & $1582.556^{* *}$ \\
Coloration period (P) & $1164.000^{* *}$ & $14763.000^{* *}$ \\
C x P & $268.444^{* *}$ & $1935.889^{* *}$ \\
Error & 49.231 & 55.077 \\
Average & 25.385 & 43.615 \\
\hline C.V. (\%) & 27.64 & 17.02 \\
\hline LSD (least significant difference) & 14.41 & 15.24 \\
\hline$* *$
\end{tabular}

${ }^{* *}=$ significant at $1 \%$ probability by the F-test; ${ }^{\mathrm{ns}}=$ nonsignificant at $5 \%$ probability by the F-test.

As for the results for the percentage of viable seeds by the tetrazolium test at different concentrations and exposure times and the germination test (control) for experiments conducted at temperatures of 30 and $35^{\circ} \mathrm{C}$, they are presented in Table 2. For the temperature of $30{ }^{\circ} \mathrm{C}$, the means of seeds viability were higher as the seed coloration period increased, although without difference between periods of 2 and 4 hours. It was found also that the means for seed viability differed from the results of the germination test (control - 78\%) for all concentrations $(0.075,0.1,0.5$ and $1.0 \%)$ and time $(2,4$ and 6 hours) tested within this temperature.

Under the temperature of $35^{\circ} \mathrm{C}$, the six-hour period of coloration gave the highest estimate of viability, regardless of the concentration of the tetrazolium solution, except at $1.0 \%$, whose estimate did not differ from the periods of 2 and 4 hours (Table 2), and higher values for coloration periods were observed at concentrations of 0.1 and $0.5 \%$. The six-hour period at concentrations of $0.075 \%$ ( $85 \%$ of viable seeds), $0.1 \%$ ( $93 \%$ of viable seeds) and $0.5 \%$ (90\% of viable seeds) was favorable for the assessment of the seeds, providing estimates similar to the results from the germination test $(78 \%)$. As for the other combinations of periods and concentrations, there was a difference between these and the control in view of the inadequate coloration, which underestimated seeds viability.
Among the tested temperatures, $35^{\circ} \mathrm{C}$ were which provided the highest viability values.

Table 2. Viable seeds of Simira gardneriana M.R. Barbosa \& Peixoto obtained by tetrazolium test at different concentrations $(0.075 ; 0.1 ; 0.5$ and $1.0 \%)$ and periods of coloration (2, 4 and 6 horas) at 30 and $35^{\circ} \mathrm{C}$ compared to the results of the germination test (control).

\begin{tabular}{|c|c|c|c|c|}
\hline \multirow{2}{*}{$\begin{array}{l}\text { Periods } \\
\text { (hours) }\end{array}$} & \multicolumn{4}{|c|}{ Concentration of tetrazolium solution (\%) } \\
\hline & 0.075 & 0.1 & 0.5 & 1.0 \\
\hline \multicolumn{5}{|c|}{ 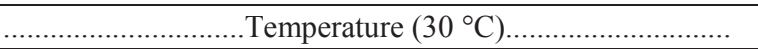 } \\
\hline 2 & 12 Aby & 15 Aby & 13 Aby & 16 Aay \\
\hline 4 & 16 Aby & 18 Aby & 20 Aaby & 20 Aay \\
\hline 6 & 43 Aay & 37 ABay & 28 Bay & 14 Cay \\
\hline \multicolumn{5}{|c|}{ 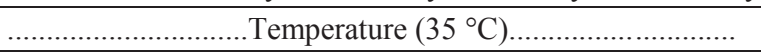 } \\
\hline 2 & 13 Aby & 13 Aby & 24 Acy & 27 Aay \\
\hline 4 & 8 Cby & 13 Cby & 57 Aby & 32 Bay \\
\hline 6 & $85 \mathrm{Aaz}$ & $93 \mathrm{Aaz}$ & $90 \mathrm{Aaz}$ & 33 Bay \\
\hline \multicolumn{5}{|c|}{ Germination $=78 \mathrm{z}$} \\
\hline
\end{tabular}

Means followed by the same uppercase letters $(\mathrm{A}, \mathrm{B}, \mathrm{C})$ in the line and lowercase $(\mathrm{a}, \mathrm{b}, \mathrm{c})$ in the column do not differ significantly at $5 \%$ probability by the Tukey's test.

Means followed by the same letter $(\mathrm{z}, \mathrm{y})$ between germination (control germination test) and viability obtained in the tetrazolium test do not differ significantly at $5 \%$ probability by Dunnett's test. 
These results support the claims observed by AOSA (2009), in which seeds coloration in the tetrazolium test settles faster at higher temperatures. For this reason, Marcos-Filho et al. (1987) recommend that seeds immersed in tetrazolium solution be placed in a chamber set at temperatures of 30 to $40{ }^{\circ} \mathrm{C}$. In this study, the best combinations for assessing the viability of $S$. gardneriana seeds were recorded at temperature $35{ }^{\circ} \mathrm{C}$ whereas at $30{ }^{\circ} \mathrm{C}$ all combinations of concentrations and periods statistically differed from the germination test.

Work involving the standardization of the tetrazolium test methodology on other species of Rubiaceae can be found, focusing on reducing the time to detect the quality of seed lots. However, there has been different results according to the species studied. Fava and Albuquerque (2013), for example, have shown that the best procedure to estimate the viability of Palicourea rigida Kunth seeds was by using the tetrazolium solution at the concentration of $0.5 \%$ at $40{ }^{\circ} \mathrm{C}$ for 3 hours. On the other hand, Zonta et al. (2009), with Coffea arabica L. seeds have found, as the best methodology to assess the seeds viability of this species, soaking for 24 hours at $30{ }^{\circ} \mathrm{C}$, removal of the embryo and exposure to tetrazolium solution at $0.1 \%$, during 16 hours at $35^{\circ} \mathrm{C}$.

Coloration patterns observed in embryos ranged from light pink in viable seeds to white in dead seed (Figure 2). Viable embryos exhibited uniform light pink or bright red colors along their entire length, demonstrating that tissues were alive and vigorous. On the other hand, unviable embryos, when exposed to tetrazolium solution, exhibited an intense red coloration (tissue deterioration) or milky white (dead tissue) in its full extent, or an intense red color only at the end of the radicle.

The choice of the appropriate method for the tetrazolium test must be based on ease of identification of viable and unviable tissues and the ability to differentiate seed vigor (Azerêdo et al., 2011). The color differences observed in the seeds after coloration in tetrazolium solution are the main features that should be considered when interpreting the test results. The color intensity of the seeds in the tetrazolium test varies among species. For example, the pink color seen in viable seeds of Leucaena (Leucaena leucocephala (Lam.) de Wit) is lighter (Costa and Santos, 2010) than that seen in seeds of Brachiaria brizantha (Hochst. ex A. Rich) Stapf (Dias and Alves, 2008). In this species, the color which indicates a viable tissue is red or deep pink. In Leucaena seeds, that deep pink color means tissue deterioration. This is because the terminology used to determine the colors observed in seeds in the tetrazolium test is usually established by the authors. Therefore they may vary among studies.

Exposure of embryos in tetrazolium solution at $30{ }^{\circ} \mathrm{C}$ was less efficient in viable seeds classification, for it presented problems for the coloration of the embryo, many did not color at the lowest concentration $(0.075 \%)$, and some only colored the ends at higher concentrations ( 0.5 and $1.0 \%)$, thus complicating the interpretation of results (Figures 2F, $2 \mathrm{G}$ and $2 \mathrm{H}$ ).
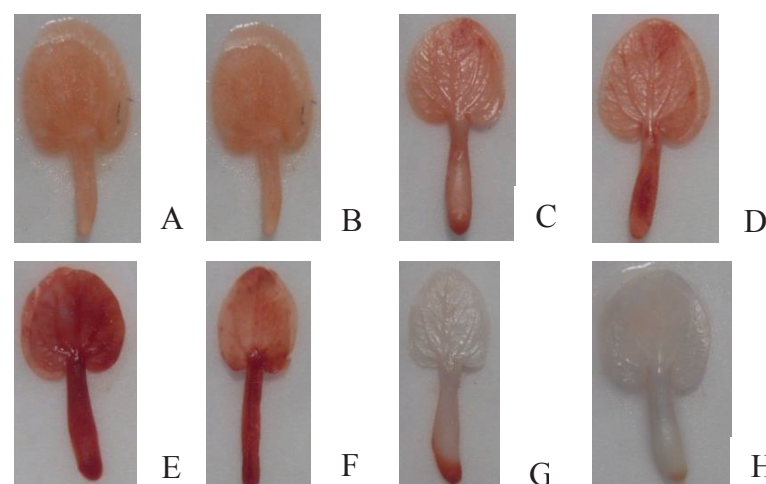

$\mathrm{E}$
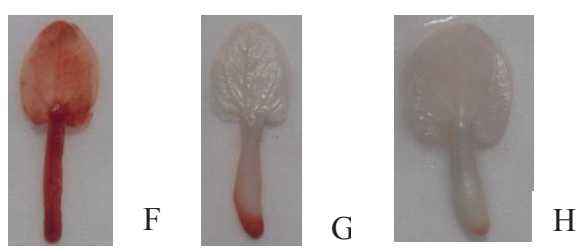

Figure 2. Viable seeds of Simira gardneriana M.R. Barbosa \& Peixoto: an embryo with light pink (A, B) and bright red (C) colorations; hypocotyl-radicle axis with an intense red coloration in the cortex, but without reaching the central cylinder (D). Unviable seeds of pereiro-vermelho (Simira gardneriana M.R. Barbosa \& Peixoto): an embryo with an intense red coloration in all its extension (E) or hypocotyl-radicle axis with an intense red coloration reaching the central cylinder $(\mathrm{F})$; an embryo with discolored/milky white and/or intense red areas reaching the central cylinder $(\mathrm{G}, \mathrm{H})$.

At $30{ }^{\circ} \mathrm{C}$, viability values at different concentrations and coloration periods did not represent the values observed in the germination test, probably due to the fact that the tetrazolium solution did not spread uniformly, thus hindering coloration and evaluation. In this case, embryos that did not develop optimal coloration may have been considered unviable when the absence of coloration could have been caused by the incubation temperature, combined with different concentrations and times. It was also observed that in many embryos exposed at the 0.5 and $1.0 \%$ concentrations, an intense red coloration developed at the ends of the plumule or bottom of the hypocotyl-radicle axis (Figure 2F), probably because these areas were more exposed to tetrazolium solution than the others.

In the evaluation of the tetrazolium test of $S$. gardneriana seeds at a temperature of $35^{\circ} \mathrm{C}$, variations were observed in the seeds coloration according to the treatments used, and light shades were observed at the lowest concentration of the tetrazolium solution $(0.075 \%)$. The coloration periods of 2 and 4 hours were insufficient to estimate the viability 
of $S$. gardneriana seeds at all tested concentrations for they did not promote an adequate coloration that would enable to distinguish living from dead or damaged tissues.

On the other hand, the 6-hour coloration period was effective to assess the seeds viability of this species at concentrations of $0.075 \%, 0.1 \%$ and $0.5 \%$, for they provided a clear coloration of the embryos, facilitating the analysis and interpretation of results (Figures 2A, 2B, 2C and 2D). Furthermore, it allowed the identification of lesions in areas that are critical for the embryo, such as the hypocotyl-radicle axis. It should be noted, however, that the 6-hour coloration period, associated with a concentration of $1.0 \%$ tetrazolium solution (Figure $2 \mathrm{E}$ ) provided more than $60 \%$ of embryos with an intense red color (deteriorated seeds - unviable), different from the results obtained in the germination test (Table 2).

Tetrazolium test using concentrations of $0.075 ; 0.1$ and $0.5 \%$ during 6 hours of coloration at $35{ }^{\circ} \mathrm{C}$ was efficient to estimate the viability of $S$. gardneriana seeds. In other periods, regardless of the temperature, tetrazolium salt concentrations did not promote an adequate coloration that would enable to distinguish living from dead or damaged tissues. However, lower concentrations are more indicated by their lower salt cost and due to allowing a better visualization of the coloration disorders and identification of different types of injuries (AOSA, 2009). Thus, tetrazolium test using a concentration of $0.075 \%$ can be used as a supplement to the germination test in assessing the viability of $S$. gardneriana seeds.

\section{Conclusions}

The pre-wetting of $S$. gardneriana seeds for 144 hours in the preparation phase for performing the tetrazolium test facilitates the extraction of embryos and does not affect the test results.

Tetrazolium salt concentration at $0.075 \%$ for six hours at $35{ }^{\circ} \mathrm{C}$ is an effective combination to assess the viability of $S$. gardneriana seeds.

\section{Acknowledgments}

To the Centro de Referência para Recuperação de Áreas Degradadas da Caatinga (Reference Center for Recovery of Degraded Areas of the Caatinga) at Federal University of São Francisco Valley (UNIVASF, Universidade Federal do Vale do São Francisco) (CRAD/UNIVASF) represented by Dr. José Alves de Siqueira Filho, for granting the seeds used in the experiment.

\section{References}

ABBADE, L.C.; TAKAKI, M. Teste de tetrazólio para avaliação da qualidade de sementes de Tabebuia roseoalba (Ridl.) Sandwith - Bignoniaceae, submetidas ao armazenamento. Revista Árvore, v.38, n.2, p.233-240, 2014. http://www.scielo.br/pdf/rarv/v38n2/03.pdf

AOSA. Association of Official Seed Analysts. Seed vigor testing handbook. Ithaca, 2009. 340p.

AZERÊDO, G.A.; PAULA, R.C.; VALERI, S.V. Viabilidade de sementes de Piptadenia moniliformis Benth. pelo teste de tetrazólio. Revista Brasileira de Sementes, v.33, n.1, p.61-68, 2011. http://www.scielo.br/pdf/rbs/v33n1/07.pdf

BARBOSA, M.R.V.; PEIXOTO, A.L. A new species of Simira (Rubiaceae, Rondeletieae) from Northeastern Brazil. Novon, v.10, n.2, p.110-112, 2000 https://www.jstor.org/stable/3393006?seq=1\#page_scan_tab_contents

BRASIL. Ministério da Agricultura, Pecuária e Abastecimento. Regras para análise de sementes. Ministério da Agricultura, Pecuária e Abastecimento. Secretaria de Defesa Agropecuária. Brasília: MAPA-ACS, 2009. 395p. http:// www.agricultura.gov.br/arq_editor/file/2946_regras_analise_sementes.pdf

COSTA, C.J.; SANTOS, C.P. Teste de tetrazólio em sementes de leucena. Revista Brasileira de Sementes, v.32, n.2, p.66-72, 2010. http://www.scielo. br/pdf/rbs/v32n2/v32n2a08.pdf

CRIPA, F.B.; FREITAS，L.C.N.; GRINGS，A.C.; BORTOLINI，M.F. Tetrazolium test for viability estimation of Eugenia involucrate DC. and Eugenia pyriformis Cambess. seeds. Journal of Seed Science, v.36, n.3, p.305-311, 2014. http://www.scielo.br/pdf/jss/v36n3/aop0514.pdf

DIAS, M.C.L.L.; ALVES, S.J. Avaliação da viabilidade de sementes de Brachiaria brizantha (Hochst. ex A. Rich) Stapf pelo teste de tetrazólio. Revista Brasileira de Sementes, v.30, n.1, p.145-151, 2008. http://www. scielo.br/pdf/rbs/v30n1/a26v30n1.pdf

FAVA, C.L.F.; ALBUQUERQUE, M.C.F. Viabilidade e emergência de plântulas de Palicourea rigida Kunth em função de diferentes métodos para superação de dormência. Enciclopédia Biosfera, v.9, n.17, p.26202629，2013. http://www.conhecer.org.br/enciclop/2013b/CIENCIAS\%20 AGRARIAS/VIABILIDADE\%20E\%20EMERGENCIA.pdf

GASPAR-OLIVEIRA, C.M.; MARTINS, C.T.; NAKAGAWA, J. Método de preparo das sementes de mamoneira (Ricinus communis L.) para o teste de tetrazólio. Revista Brasileira de Sementes, v.31, n.1, p.160-167, 2009. http:// www.scielo.br/pdf/rbs/v31n1/a18v31n1.pdf

KAISER, D.K.; FREITAS, L.C.N.; BIRON, R.P.; SIMONATO, S.C.; BORTOLINI, M.F. Adjustment of the methodology of the tetrazolium test for estimating viability of Eugenia uniflora L. seeds during storage. Journal of Seed Science, v.36, n.3, p.344-351, 2014. http://www.scielo.br/pdf/jss/ v36n3/10.pdf

LAMARCA, E.V.; BARBEDO, C.J. Methodology of the tetrazolium test for assessing the viability of seeds of Eugenia brasiliensis Lam., Eugenia uniflora L. and Eugenia pyriformis Cambess. Journal of Seed Science, v.36, n.4, p.427-434, 2014. http://www.scielo.br/pdf/jss/v36n4/aop1114.pdf

LAZAROTTO, M.; PIVETA, G.; MUNIZ, M.F.B.; REINIGER, L.R.S Adequação do teste de tetrazólio para avaliação da qualidade de sementes de Ceiba speciosa. Semina: Ciências Agrárias, v.32, n.4, p.1243-1250, 2011. http://www.uel.br/portal/frm/frmOpcao.php?opcao=http://www.uel.br/ revistas/uel/index.php/semagrarias 
MARCOS-FILHO, J.; CÍCERO, S.M.; SILVA, W.R. Avaliação da qualidade das sementes. Piracicaba: FEALQ, 1987. 230p.

NOGUEIRA, N.W.; TORRES, S.B.; FREITAS, R.M.O. Teste de tetrazólio em sementes de timbaúba. Semina: Ciências Agrárias, v.35, n.6, p.29672976, 2014. http://www.uel.br/revistas/uel/index.php/semagrarias/article/ view/14704/pdf_521

OLIVEIRA, L.M.; CARVALHO, M.L.M.; DAVIDE, A.C. Teste de tetrazólio para avaliação da qualidade de sementes de Peltophorum dubium (Sprengel) Taubert - Leguminosae Caesalpinioideae. Cerne, v.11, n.2, p.159-166, 2005 a.

OLIVEIRA, L.M.; CARVALHO, M.L.M.; NERY, M.C. Teste de tetrazólio em sementes de Tabebuia serratifolia Vahl Nich. e T. impetiginosa (Martius ex A. P. de Candolle) Standley - Bignoniaceae. Revista Ciência Agronômica, v.36, n.2, p.169-174, 2005b. http://www.ccarevista.ufc.br/seer/index.php/ ccarevista/article/view/264/259
SILVA, F.A.S.E.; AZEVEDO, C.A.V. Versão do programa computacional Assistat para o sistema operacional Windows. Revista Brasileira de Produtos Agroindustriais, v.4, n.1, p.71-78, 2002. http://www.deag.ufcg.edu.br/rbpa/ rev41/Art410.pdf

ZONTA, J.B.; SOUZA, L.T.; DIAS, D.C.F.S.; ALVARENGA, E.M. Comparação de metodologias do teste de tetrazólio para sementes de cafeeiro. Idesia, v.27, n.2, p.17-24, 2009. http://www.scielo.cl/pdf/idesia/v27n2/art02.pdf 